\title{
Atypical Rulings of the Indonesian Constitutional Court
}

\author{
Bisariyadi \\ Research Center and Assessment of the Constitutional Court of the Republic of Indonesia \\ Jl. Medan Merdeka Barat No. 6, Jakarta, 10110, Indonesia \\ Tel./Fax:+62-21-3520177E-mail: bisariyadi@mahkamahkonstitusi.go.id \\ Submitted: May 16, 2016; Reviewed: Jun 21, 2016; Accepted: Jun 28, 2016
}

\begin{abstract}
In deciding judicial review cases, the Court may issue rulings that is not in accordance to what is stipulated in the Constitutional Court Law (Law Number 8 Year 2011). Atypical rulings means that the court may reconstruct a provision, delay the legislation/rulings enactment or give instruction to lawmakers. In addition, the court also introduce the "conditionally (un)constitutional" concept. This essay attempts to identify and classify these atypical rulings, including conditionally (un)constitutional rulings, by examined the constitutional court judicial review rulings from 2003 to 2015. This study will provide a ground work for advance research on typical rulings by the Indonesian constitutional court.
\end{abstract}

Keywords: Constitutional Court; Court Rulings; Conditionally (un)Constitutional; Positive Legislature

DOI: http://dx.doi.org/10.20956/halrev.v1n2.306

\section{INTRODUCTION}

The Indonesian Constitutional Court (Mahkamah Konstitusi, MK) is consider as an activist court. ${ }^{1}$ One of the reasons that drive scholars to such conclusion is that MK, in a number of times, issued special rulings. By special ruling means that the Court might choose to reconstruct a statute to ensure its compliance with the constitutional provision, postponed the enactment of decisions

\footnotetext{
Bjorn Dressel. (2012) 'The Judicialization of Politics in Asia: Towards a Framework of Analysis'. in Bjorn Dressel (ed). The Judicialization of Politics in Asia. Routledge, London, pp. 1-22; see also Simon Butt. (2007). Judicial Review in Indonesia: Between Civil Law and Accountability? (PhD Dissertation, Melbourne University)
}

or give orders to lawmakers. These models can be found in a single ruling or the court compose it independently.

In the context of court rulings to reconstruct a statute, MK coin a phrase "conditionally (un)constitutional". The Law on $\mathrm{MK}^{2}$ provide that in judicial review cases the court shall issue decisions of "inadmissible", 3 "granted"4 or "rejected".

2 Law No. 24 Year 2003 on The Constitutional Court (as amended by Law No. 8 Year 2011)

3 According to article 56 (1) Law on MK, if the court find the petitioner did not meet the standing requirements or if the issue presented was not in the authorities of the Court, the petition shall be resolved "inadmissable"

4 According to article 56 (2) Law on MK, if the court concur with the petitioner's arguments it shall be decided "granted"

5 According to article 56 (5) Law on MK, if the court 
Yet, "conditionally (un)constitutional" rulings stand in between decision of "rejected" and "granted". In "conditionally constitutional" ruling, the court finds the statute is in conformity with the constitution only if it met the term(s) given by the Court. On the opposite, "conditionally unconstitutional" ruling issue when the Court finds the statute against the constitutional principle on the condition that stipulated in the ruling. In principle, there is no difference between conditionally constitutional and conditionally unconstitutional. The Court was simply playing with positive and negative formula. However, a different repercussion of rulings leads the Court to change from positive to negative formula. The Court discover the fact that stating a statute in positive does not draw the attention of lawmakers to comply with the rulings. ${ }^{6}$ The situation prompt the court to use the opposite approach. By declaring a statute "conditionally unconstitutional" is parallel to invalidating a statute. This would put the ruling into the lawmakers radar. Nonetheless, MK uses these approach inconsistently. Although claiming that the positive formula is not compelling, the Court still apply it.

These special rulings are not unique to the constitutional court or they are new in the practice of constitutional law. There are examples in many countries that exercise such decisions and apply them far before MK established. MK and other constitutional courts apply such decision in order to fill a legal gap that potentially occur if the statute under review annulled. Outcome of

finds the law in review were not breach the constitution the the court shall pronounce the decision "rejected"

6 Rulings No. 54/PUU-VI/2008, para. [3.22] invalidating a statute can be detrimental to the constitutional rights and to governmental interests since the decision produces erga omnes effects. ${ }^{7}$ It is important for courts to seek balances and produces a decision that does less harm to the individuals whose rights are at risk.

However, as it happened in many quarters, the feature of such rulings have been attacked by other branches of government. The reason behind this attack is based on the notion that courts should not free to repair statutes according to their direction. Kelsen's notion of constitutional court as "negative legislature" and parliament as "positive legislature" contribute heavily to this discourse. His idea of the court as a negative legislature was to indicate that it has the power to invalidate legislation that is enacted by parliament. But, Kelsen never intended to make strict distinction that court act only as negative legislature. On the contrary, Kelsen even suggests that the court can act as positive legislature. ${ }^{8}$

This notion has often use inaccurately and, most of the time, separation of power principle also employ to only add more bemusement to the debate. To make matter worse, formalistic approach in the civil law system adding the controversies. In civil law countries, Indonesia is one of them, judges are not entitled to extend or restrict the norm. The adoption of special rulings in the Court

\footnotetext{
Victor Ferreres Comella. (2011). "Commentary: Courts in Latin America and the Constraints of the Civil Law Tradition”. Texas Law Review. 89(1): 172-174

8 Hans Kelsen. (1942). "Judicial Review of Legislation: A Comparative Study of the Austrian and the American Constitution". The Journal of Politics. 4(2):183 as cited in Victor Ferreres Comella. (2004). "The European Model of Constitutional Review of Legislation: Toward Decentralization?'. International Journal of Constitu-
} tional Law. 2(3): 487 
pushes the boundaries of civil law tradition. Judges, specially constitutional judges, in the civil law countries becomes positive legislature. The discussion will further be addressed in this essay.

MK has adopted this type of special rulings since 2005 when the court examine water resources case. ${ }^{9}$ In this ruling, MK introduces "conditionally constitutional" and mention it in the chapter of Court Opinion (Pertimbangan Hukum). Subsequently, it evolves. The rulings, later, was install in the Court Order (Amar Putusan) to give more clout on the effect of the rulings. There are 108 rulings where the Court issued conditionally (un)constitutional status of a statute, from 2005 to $2015 .{ }^{10}$ However, in such a large materials that can be examined, academic papers dedicated to this topic are relatively small. This essay will not tackle to fill those gap, for it is too ambitious and an article will not be sufficient. It attempts to give a brief description, as well as contribute categorization of rulings issued by $\mathrm{MK}$ from 2005 to 2015 for further study.

The attempt to classify court special rulings is not unfamiliar. Allan R. BrewerCarias initiated a comparative study which offers a general classification of court rulings to the extend of the court as positive legislators. ${ }^{11}$ This classification is worth notice in

9 Rulings Number 058-059-060-063/PUU-II/2004 and 008/PUU-III/2005, the review of La Number 7 Yera 2004 on Water Resources

10 See annex I.

11 He identify that there are 4 trends in regards to the relation of the Constitutional Court with the legislator, namely (i) interfere with the constitutent power, enacting constitutional rules and mutating the Constitution, (ii) interfere with existing legislation, assuming tasks as legislator assistant, complementing statutes, adding new provision, determinging temporal effect of legislation, (iii) interfere with the absence of legislation (iv) acting as legislators on matters of judicial review. For the attempt of making categorization of special rulings in the Indonesian context. This essay will not only focus on rulings which declare "conditionally (un)constitutional". Other groups of special rulings, such as issuing directives to legislators and postponing the effect of the court rulings which are issued independently also be considered. ${ }^{12}$ Yet, strict categorisation is futile since a ruling may consist of criteria which can be included in different groups. ${ }^{13}$

This essay divided into four parts. The first part is the introduction. The second part will discuss on the legitimacy of the Court to issue such special ruling and the problems that courts have to encounter. Such problems derive from other branches of government, usually parliament, that reluctant by the notion that courts have the authority to reconstruct a statute, especially from countries which adopted civil law system like Indonesia. The classification of conditionally (un)constitutional with a brief discussion on the rulings will constitute part

further discussion see Allan R. Brewer-Carias (2013) Constitutional Courts as Positive Legislators: A Comparative Law Study, Cambridge University Press.

12 The court may apply decision to postponed the enactment of the decision independently without refering to the conditionally constitutional approach. For instance in Ruling number 012-016-019/PUU-IV/2006, the Court postponed the establishment of special court for corruption cases within three years after the deliberation of the Ruling. In Rulings Number 14/PUU$\mathrm{XI} / 2013$, the Court also postponed its enactment on the unconstitutionality of the norms which rules different schedule for legislative and presidential election. The Court are in favor of legislative and presidential election shall be held simultaneously. But, considering the moment of the rulings being announce are close to the election day of 2014, the court postponed its judgment and saying that the rulings shall be implemented in the next election year, 2019.

13 For instance, in rulings no. 54/PUU-VI/2008 the court holds that the provision is unconstitutional unless new rules were applied. In the same time, the court also postponed the enactment of the new rule to prevent mal-administration in the annual state budget. 
three of this essay. Lastly, a summary will be presented in conclusion.

\section{ANALYSIS AND DISCUSSION}

\section{The Court as Positive Legislature}

The issuance of special rulings is not unique. There are number of practices in many quarters which constitutional courts crafted creative judgments. The Italian Constitutional Courts issue so-called manipulative judgment (sentenze monito), ${ }^{14}$ which basically have similarity with MK's conditionally (un)constitutional rulings. The Italian Constitutional Court manages to insert new rule which cannot be found in the satutory text. In another version, the Italian Court does not insert new rules but only stipulate principles that the parliament must implement which is known as "additive di principio. ${ }^{15}$ Brazilian Constitutional Court (Supremo Tribunal Federal, STF) use the same technique as observers called it as interpretative judgment. ${ }^{16}$ It also a common feature in the Central and Easterns European countries, especially those in Hungary, Poland, and Slovenia. ${ }^{17}$

14 Simone Penasa. "Constitutional Innovations Beyond Reforms: Legislative Enactment And Judicial Implementation Of The Constitution". in Giuseppe Bellantuono and Federico Puppo (eds.). (2015) Convergences And Divergences Between The Italian And The Brazilian Legal Systems. Università degli Studi di Trento. p. 47; see also Giancarlo Rolla and Tania Groppi. "Between Politics and the Law: The Development of Constitutional Review in Italy" in Wojciech Sadurski (ed). (2003). Constitutional Justice, East and West: Democratic Legitimacy and Constitutional Courts in PostCommunist Europe in a Comparative Perspective., The Hague-London-New York: Kluwer Law International. pp. $151-153$

15 Giancarlo Rolla and Tania Groppi, ibid.

16 Leo Brust. (2009). "The Interpretation According to the Constitution and the Manipulative Judgments". Revista Direito GV Sao Paolo. 5(2): 136-152

17 Wojciech Sadurski. (2008). Rights Before Courts, A Study of Constitutional Courts in Postcommunist States of Central and eastern Europe. the Netherlands: Springer.
The issuance of this type of decision plays a crucial role for courts to gain high prestige among other political branches in the law-making role. As observers recall "powerful constitutional courts frequently offer direct and specific instruction on how an unconstitutional statute can be redrafted into constitutionality". ${ }^{18}$ For instance, the German Constitutional Court in its landmark decision on abortion case ${ }^{19}$ not only declare to annulled the statute, the Court goes further and directed the parliament by ordering "in the extreme case, if the protection required by the constitution cannot be realized in any other manner, the legislature is obligated to employ the criminal law to secure the life developing itself'" ${ }^{20}$

The justification for the robust position of the constitutional courts is based on the role of courts in the protection of individual rights. It has been accepted that constitutional courts must have strong powers to monitor the constitutionality of legislation if constitutional rights are to be meaningful. ${ }^{21}$ In a democratic system, there must be a protector of minority rights against majoritarian abuse, and that constitutional courts are well suited to perform such a role. Nonetheless, Kelsen has warned the danger of installing rights in constitutions. He further goes on saying that rights adjudication would distort the negative and the positive legislator distinction. ${ }^{22}$ Alec Stone conclude on Kelsen's

18 Martin Shapiro and Alec Stone Sweet. (1994). "The New Constitutional Politic of Europe". Comparative Political Study. 26(4): 404.

1930 Entscheidungen des Bundesverfassungsgerichts [BverfDE], Federal Constitutional Court, 1 (1975)

20 Vicki C. Jackson and Mark Tushnet. (2006). Comparative Constitutional Law. 2nd edition. New York: Foundation Press. p. 112

21 Wojciech Sadursky, Loc. Cit, p. 62

22 Hans Kelsen, "The Jurisdictional Protection of the 
remarks that constitutional judges become positive legislators to the extent that they protect rights. ${ }^{23}$ However, a scholar denies the use of "positive legislature" approach for justification of court's legitimacy to readjust a statute instead of declaring it unconstitutional. ${ }^{24}$ Comella argues that Kelsen also points out that sometimes the court should act as positive legislature to fill a gap in the legal system. Nevertheless, such act, to continue what Kelsen have in mind, only rest in a review of a specific clause in the constitution while protecting a more abstract, for instance, "justice" and "equality" should stay in the hand of parliament. ${ }^{25}$

As for the practices in Indonesia, judicial review cases examined by MK mostly involved infringement of constitutional rights. Nonetheless, as MK only perform an abstract review, the absence of rights in the court opinion is plausible. Law on MK enables parties ${ }^{26}$ to submit cases not exclusively on rights infringement but also for encroachment of their authorities, particularly state bodies. Parties can argue potential loss with prudent approaches by which it will occur due to the imposition of laws. For instance, in the review of the House of Regional Representatives (Dewan Perwakilan Daerah, DPD) authority, ${ }^{27}$ the Court did not

Constitution", as cited in Alec Stone Sweet. (2007) "The Politics of Constitutional Review in France and Europe," International Journal of Constitutional Law. 5(1). p. 84

23 Ibid.

24 Op. cit. Victor Ferreres Comella, "The European model of constitutional review of legislation: Toward decentralization?". p. 487

25 Ibid.

26 Article 51 of Law on MK, specify four parties that have standing on judicial review cases, namely: (a) individual, (b) indigenous people, (c) legal/private entity, and (d) state institution.

27 Case/Rulings Number 92/PUU-X/2012 consider any violation of rights. The case was brought by DPD itself asking the Court to examine its roles in legislation drafting. The Court put article 20 (2), 22D (1) and 22D (2) of the Constitution to the test ${ }^{28}$ in consideration whether the constitutional authorities of DPD have been or will be breached. In its rulings, MK inserts new rules which extend the function of DPD in a legislative process.

The assertive role that the constitutional court play may sometimes draw resistance from lawmakers. They abide the idea that court can modify the language of the statutory text in judicial review case and charged the court has acted ultra vires. It happened in Indonesia. The Parliament (Dewan Perwakilan Rakyat, DPR) and the President, as lawmakers, passed a revision of Law on MK which reduces the Court's role. ${ }^{29}$ The Law consist articles that forbid the Court to issue rulings further beyond what the applicant asked. ${ }^{30}$ It also limits the Court Order to exclude directive for lawmakers and insert new rules to the statutory text. ${ }^{31}$ The adoption of civil law system, which Indonesia embrace, contributes heavily to this discussion. Civil law tradition attempts to insulate the legal

28 Article 20 (2) stated "Each bill shall be discussed by the DPR and the President to reach joint approval." Article 22D (1) and (2), stipulated: (1) The DPD may propose to the DPR Bills related to regional autonomy, the relationship of central and local government, formation, expansion and merger of regions, management of natural resources and other economic resources, and Bills related to the financial balance between the centre and the regions; (2) The DPD shall participate in the discussion of Bills related to regional autonomy; the relationship of central and local government; formation, expansion, and merger of regions; management of natural resources and other economic resources, and financial balance between the centre and the regions; and shall provide consideration to the DPR over Bills on the State Budget and on Bills related to taxation, education, or religion.

29 Law Number 8 year 2011.

30 Article 45A Law 8/2011

31 Article 57 section (2a) Law 8/2011 
system from politics, religion, economics, which is not purely law. Therefore, judges are not supposed to play a major role in defining policy since it is the duty of the legislature. ${ }^{32}$ Civil law culture also tends to be "formalist" in a sense that it put emphasis on written legal provisions and on the relevance of linguistic to assign meaning. Judges are not entitled to deviate from the norm. Therefore, in civil law tradition, judges should not extend or restrict the norm to make it better. ${ }^{33}$

The court has the availability to examine the constitutionality of these articles after an Indonesian citizen lodges an application to review the Law. ${ }^{34}$ The court argues that the enforcement of articles in question have the effect of obstructed the court to (i) carry out its obligation of constitutional review (ii) fill the legal gap, and (iii) perform the justices duty to establish the constitution as living law. ${ }^{35} \mathrm{MK}$ also assert that the prohibition of the court to crafted so-called ultra-petita judgment by borrowing from legal doctrine in civil procedure law is misleading since the nature of constitutional cases are far cries from civil law cases. It is become a common practice in constitutional law where the court assume an article in South Korean Law on the Constitutional Court which stipulates:

"...if it is deemed that the whole provisions of the statute are unable to enforce due to a decision

32 Op. Cit. Vicki C. Jackson and Mark Tushnet,. p. 467468

33 Op. Cit. Victor Ferreres Comella, "Commentary: Courts in Latin America and the Constraints of the Civil Law Tradition". p 1971

34 Case Number 48/PUU-IX/2011. An Indonesian citizen, Fauzan, filed a judicial review case on Narcotics Law (Law No. 35/2009). He asked the court to issue a conditionally constitutional rulings on Narcotics Law. In order to achieve it, he, firstly, argue the need to struck down Article 45A and 57 (2a) of Law 8/2011.

35 Ibid, Paragraph [3.13] of unconstitutionality of the requested provision, a decision of unconstitutionality may be made on the whole statute". ${ }^{36}$

The Court, then, struck down the articles on ground that they were against the constitution. This case is a challenge for the court to test its institutional legitimacy strength. The ability of the court to nullify rules which reduce its power without any retaliation shows increasing support for its legitimacy. ${ }^{37}$

Nonetheless, it is detrimental to a democracy, where the court exercises enormous power of making policy, there have to be a proper balance of power between judicial and legislative institutions. Judicial review is compatible with democracy as long as judges control "legitimate processes" instead of "legitimate outcomes". ${ }^{38}$ But, it is not illegitimate for the court to decide on legitimate outcomes as well. As Landfried argues there are strict criteria in which judges of the court can be involved in the examination of legitimate outcomes, namely (i) the commitment of a decision to the constitutional text, (ii) the rationality of the argument, and (iii) the constitutional system of separation of powers. ${ }^{39}$ She also noted that there is no genuine system of separation of

36 Article 45 of South Korean Law on the Constitutional Court (1987) as cited in the Court Rulings Number 48/ PUU-IX/2011.

37 Fritz Edward Siregar. (2015). "the Political Context of Judicial Review in Indonesia". Indonesia Law Review. 2(2): 235

38 John Ely. (1982). Democracy and Distrust: A Theory of Judicial Review. 4th edition. Cambridge, MA: Harvard UP. p. 45, as cited in Christine Landfried. "Judicial Policy Making in Germany: The Federal Constitutional Court". pp 63-65, in Mary L. Volcansek (ed.). (1992) Judicial Politics and Policy-Making in Western Europe. Londong: Frank Cass.

39 Ibid. 
power, therefore, a clear distinction of constitutional court as negative legislature and parliament as positive is unattainable.

\section{Typology of Atypical Rulings}

After the introduction of conditionally constitutional concept the court ventures certain phases in order to give more weigh in the concept. Firstly the Court formulated the conditionally constitutional approach was in the examination of water law case. The approach was part of the court opinion whereby it stated: ".. if in the implementation of the Law (under review) was translated not in accordance to the court, the Law is prone to be the object of review [conditionally constitutional]." 40 Another ruling which stated the conditionally constitutional approach as part of the opinion was in rulings of National Social Security System Law case $^{41}$, case No. 14-17/PUU-V/2007 on the requirement to sit in public offices, ${ }^{42}$ case no. 29/PUU-V/2007 on censorship ${ }^{43}$. These are among the rulings which touch on conditionally constitutional in the opinion.

40 Rulings Number 058-059-060-063/PUU-II/2004 and 008/PUU-III/2005, p. 495

41 Rulings No. 007/PUU-III/2005, p.271, the court deliberated that article 5 (1) of Law 40 Year 2004 on National Social Security System is in conformity with the Constitution as far as it is translated that the institution to handle social security service only establish a national level.

42 The court emphasize that law makers should made meticulous distinction on the requirements of person to sit as public official. The requirements should not be one-siz e-fits-all category. The law makers should distinguished upon (i) elected and appointed officials; (ii) public official sits in executive branches or in legislative organs; (iii) public officials which demand public trust such as judges, law makers and public official which responsible for state budgets

43 Review of Law No. 8 year 1992 on Film. The Court maintain the existence of censorship organs to refrain from legal vacuum which leads to legal uncertainty. Nonetheless, the organs, as the Court warned, needs to endorse its democratic character and uphold human rights.
Later, to emphasize the conditionality of constitutional sets by the court, it shifted to the Court Order chapter. This model initially start in rulings on the case no. 10/ PUU-VI/2008. The case was brought by a number of parties where the Court have split decision on standing issue. ${ }^{44}$ The applicant raises a question on whether the domicile of a candidate is essential requirement for a person to run for DPD. The Court believe it is a constitutional requirement for a person to run for DPD based on their residence. Although, the constitution touch upon the issue implicitly. It is necessary for the lawmakers to clearly assert it in the laws. ${ }^{45}$

However, the court faces a problem since the law did not specify it. The court deems on a few options on how the court should respond to the problem. ${ }^{46}$ The court decided that requirement of a candidate to run for DPD is in accordance with the constitution as far as it includes the notion of the candidate must run only from the province of their residence area. The Court use conditionally constitutional approach by inserting a new rule to the statutory text. The decision came with the split bench. Three judges were dissent. ${ }^{47}$ Amongst the

44 There are four groups submitted the case, namely: (1) DPD as state institutions, (2) members of DPD acted as individual, (3) individuals acted as representative of civil society organisation, and (4) individuals represent regions in which they reside. The judges different opinions on petitioner's standing can be found in Paragraph [3.18.2] of the rulings.

45 Ibid. Paragraph [3.23]

46 Ibid. Paragraph [3.26]

47 The dissenting judges were H.A.S. Natabaya, I Dewa Gede Palguna, and Moh. Mahfud MD. Mahfud position on this matter was puzzling. He promote restrain on the Court before he appointed as judge and also when become one of the bench. But, later he grasp the idea of activism when he was Chief Justice. For further discussion see Stefanus Hendrianto (2016). "The Rise and Fall of Heroic Chief Justices: Constitutional Politics and Judicial Leadership in Indonesia". Washington 
issue that was put into account was how the Court answered. The opinion of the dissenters contended by the notion of the court embedded a new text to the Law for it is the act of the legislature. By doing so, they added, the court has altered its very nature as negative legislature and transform into a political institution. ${ }^{48}$ In addition, the court's use of the conditionally constitutional model raise a concern for it may not go all together with the rule of law. ${ }^{49}$

The next phase is where the Court shift the conditionally constitutional to conditionally unconstitutional. The court introduces negative formula (conditionally unconstitutional) in rulings 54/PUU-VI/2008. ${ }^{50}$ In contemplating legal argument presented by petitioner, the court concurs that the article in question is breaching the constitutional principle, especially article 33(4) of the Constitution which acknowledges the principles of national economic democracy. Nonetheless, to declare the article null and void would only add more damage to the petitioner since it would only mean that they will never receive their share of tobacco excise. The court was in favor to provide a more detailed clause (rechtsverfijning) by adopting conditionally

International Law Journal, 2016, Forthcoming. pp 3650. Can be access at http://papers.ssrn.com/sol3/papers. cfm?abstract_id=2629349.

48 Ibid. Paragraph [6.1] p. 223

49 Simon Butt. (2008) "Conditional Constitutionality, Pragmatism and the Rule of Law". Sydney Law School Research Paper No. 09/28. Available at SSRN: http:// ssrn.com/abstract $=1400413$

50 The case was submitted by the Governor of Nusa Tenggara Barat Province, representing the Provincial Government. The petitioner asked the court to review articles which regulated the share of tobacco excise. In practice, the excises only be enjoyed by the province which possess cigarette plant. Nusa Tenggara Barat, as province which produce tobacco do not retain benefit. The petition requested the Court to hold that Nusa Tenggara Barat province as the producer of tobacco can enjoy the share from tobacco excises. constitutional approach. ${ }^{51}$ Yet, the court argues, learning from past practices, that conditionally constitutional rulings were ineffective since the lawmakers was not comply to it instantly. ${ }^{52}$ The court twisted the rulings to a conditionally unconstitutional. It means that the article is unconstitutional unless the condition were met. The condition that the Court impose is to include the petitioner to enjoy their share from tobacco excise.

In theory, there is no difference between the formula of conditionally constitutional and conditionally unconstitutional. But, there is a practical difference. The formula of conditionally unconstitutional means that the article is against the constitution unless the court's conditions applied. If the court declares a statute is unconstitutional, according to the Law on MK, the rulings have to be published in official bulletin. ${ }^{53}$ The official bulletin is not similar to official gazette. The gazette is a media only for the announcement of legislation.

On the other side, the bulletin channeled as an authorized medium for the government to inform the public on any legal information, such as laws, regulation, and decrees. Public announcement on legislation have a very important place in civil law system. A law enter into force after it is published. It is to fulfill the axiom in civil law tradition that "everyone presume to notice the law" [Eidereen Wordt Geacht De Wette Kennen (Dutch)]. However, in court rulings, the obligation to publish in official bulletin

\footnotetext{
51 Rulings 54/PUU-VI/2008, paragraph [3.21]

$52 \quad$ Ibid. Paragraph [3.22]

53 Article 57 (3) of the Law on MK stipulated "the Court ruling which declared the application is granted must be publish in official bulletin not later than 30 days after its deliberation."
} 
did not alter the rulings date to came into force. The Law on MK stipulated that the rulings come into effect after its deliberation in an open hearing. ${ }^{54}$ This practice has a similarity with the Italian constitutional court. In Italy, only the decisions that declare a statute unconstitutional are formally recognized by the legal system to have erga omnes effects. For the Court to prevail it has to say that the statute is unconstitutional if it is interpreted in a certain way or unless it is interpreted in a certain way. ${ }^{55}$

\section{Adding new rules to the existing provision}

By adding new rules means that the Court manages to insert new rules to the existing provision and giving it a new meaning. The Court are in the views of abolishing a provision alone would not give answers to the constitutional problems. Yet, adding new rules will offer a remedy to the violated constitutional rights. New rules entail the court to create additional sentences to the provision, set up conditions needs to apply or refer principles that need to be incorporated. There are 43 rulings which incorporate this model. ${ }^{56}$

In judicial review case of Law number 56 year 2008 on the establishment of Tambrauw District, ${ }^{57}$ the Court added new areas to be included in the provision. The Court found that the creation of a new district based on areas of which the Law

\footnotetext{
54 Article 47 of the Law on MK

55 Victor Ferreres Comella. (2004). "The Consequences Of Centralizing Constitutional Review In A Special Court. Some Thoughts On Judicial Activism." SELA (Seminario en Latinoamérica de Teoría Constitucional y Política) Papers. 39: 14

56 See Annex II. Categorization of Conditionally (un)constitutional rulings

57 Rulings No. 127/PUU-VII/2009
}

prescribed has failed to defend the cultural identity of Papuan indigenous people's rights. Accordingly, the Court added new areas in which the new Tambrauw District shall include those areas. ${ }^{58}$

Another case which the Court provide new rules and also revised its own decision on the rules is in the examination of requirements to run for public office. In the first decision the Court pose the provision of "never been sentenced to imprisonment by a court decision which has binding force for committing a criminal offense punishable by imprisonment of five (5) years or more" is in conformity with the constitution if several conditions were met. ${ }^{59}$ Before coming to the decision, the court contemplates on past judgments. ${ }^{60}$ In the previous ruling, the court order lawmakers to review all provision regarding the requisite of ex-convicts to run for public office. Nonetheless, the lawmakers did not give any attention to the rulings.

By and large, the lawmakers put more weight to the requirement by shifting the conditions of "not dealing in" to "never been" criminally sentenced. Therefore, the court needs to emphasize on the matter. The court concludes that the provision is against the constitution unless certain conditions were fulfilled. The conditions were (1) can not be applied to elected official position (2) allowed to run 5 years after serving his imprisonment, (3) must disclose to public

\footnotetext{
58 The areas which District Tambrauw cover must included Amberbaken, Kebar, Senopi and Mubrani (which previously inculded as part of District Manokwari), and Moraid (which previously included as part of District Sorong)

59 Ruling No. 4/PUU-VII/2009 on review of Article 12(g) and Article 50 (1) g Law Number 10 year 2008 on General Election and Article 58 (f) Law Number 12 year 2008 on Local Government

60 Rulings No. 14-17/PUU-V/2007
} 
on his status as ex-convicts and (4) nonrecidivist. Afterward, the court challenge with a similar question but the provision stipulated in different laws. ${ }^{61}$ The law specifically regulates the condition for a candidate to run as head of local government. In the rulings, the court revised previous judgment acknowledge that it is erroneous to extend another form of punishment by suppressing his rights to be candidate after he finishes serving his imprisonment. Thus, if an ex-convict intends to run for public office, he only have to disclose his past as former criminal offender. The public will have the last word to decide whether he is eligible to sit in the office or not. The court abolishes three other conditions which mention in the previous ruling.

MK also employ another type of adding new rules to the provision. But, instead of adding norms, the court impose principles that need to be incorporated in the statute. In the review of the Law on Film, ${ }^{62}$ the petitioners consider that the existence of censor and censorship institution has limited their freedom of expression. The court asserts that any censorship institution must result from a consensus among film community and the state which represent wider communities. The court also imposes the need for a transparent mechanism of assessment and the mechanism to file for objection to the assessment. Accordingly, it will create a balance between citizen's right for freedom of expression and the state

\footnotetext{
${ }_{61}$ Rulings No. 42/PUU-XIII/2015

62 Ruling No. 29/PUU-V/2007 on review of Law No. 8 year 1992 on Film. Filed by respective people in Indonesian film industries (Anisa Nurul Shanty, actress; Muhammad Rivai Riza, movie director; Nur Kurniaty Aisyah Dewi, Movie producer)
}

obligation to ensure public interest. However, this condition is yet to exist and to abolish the Law would only create more damages and uncertainty. Therefore, the court decided that the existence of censor and censorship institution are to be maintained until the lawmakers enact a new Law with regard that censor and censorship institution must implement a mechanism in accordance with democratic and human rights principles.

\section{Alter the existing provision}

Unlike the first group where the court adds new rules to the provision, herein, the court change the provision in the Law and suggested that the Law must be read according to the alteration given by the Court. There are 33 rulings in which the Court change the words in the Laws and giving it a new meaning.

The Law on Juvenile Court (Law No. 3 Year 1997) define that minor, between the age of 8 to 18 and never been married, that committed crime can be brought to the Juvenile Court. The petitioners file a review case ${ }^{63}$ argue that the minimum age of criminal responsibility, set at 8 years old, is far below the international standard. They ask the Court to adjust the minimum age for children to 12 years old. The Court concur with the petitioner's argument. The Court also add that setting the minimum age for children to hold criminal responsibility at 12 years old is a common practice in other countries as well as recommended by the UN Children's Rights Committee. It is also taking into account that children, at age 12,

\footnotetext{
63 Ruling No. 1/PUU-VIII/2010, filed by Indonesian Children Protection Commission and the Foundation of Center for Study and Children Protection of Medan
} 
are relatively own emotional intelligence, mental, intellectual and stable and in line with child emotion and culture of Indonesia, so it can be held legally responsible for having to know their rights and obligations. Thus, the court, in its decision alter the minimum age for children to be brought to Juvenile Court to 12 years old stating that the provision is unconstitutional unless the minimum age of 8 years old has to be read as 12 years old.

In the question of constitutional mechanism to select the speakers of People's Consultative Assembly (Majelis Permusyawaratan Rakyat, MPR), raised by members of DPD, the court also alters a provision in the Law on Parliament (Law Number 27 Year 2009). ${ }^{64}$ The Law stipulated that the speakers of MPR shall be appointed in the plenary session. In its deliberation, the court concedes its nature as "negative legislator". ${ }^{65}$ It hinders the court to create new norms unless some urgent and crucial political situation emerges. In normal condition, the court shall only invalidate part of provision or the whole provision in the statute and arrange an interpretation in order to make the provision in conformity with the constitution. ${ }^{66}$ The court argument is bewildering since the court is silent on the present political situation, especially regarding the speaker of MPR selection. Yet, the court comes to the conclusion that by altering the mechanism of selection the speakers of MPR through a way of "appointment". The court held it unconstitutional unless it is read the process is by "election".

The court also meticulously alter a

64 Rulings Number 117/PUU-VII/2009

65 Ibid, paragraph [3.15]

66 Ibid. provision which claims to have editorial errors. In rulings no. 17/PUU-X/2012, the court examine a provision of criminal sanction for a state official. ${ }^{67}$ There is nothing wrong with the substance of the provision. However, the provision refers to an inaccurate article of the Law. The provision stated, "Every state official who deliberately breach article ' 83 ' [emphasis added] can be imposed of the sentence to jail in a minimum of 1 month or maximum of 6 months and/or of paying fine in minimum of six hundred thousands rupiah or maximum of six millions rupiah." Article 83 of the Law, as referred by the provision, contains articles on campaign fund. The provision supposes to refer to article 80 of the Law which regulate the restriction for a state official. Article 80 of the Law stipulated that "state official are prohibited to enacted policies that give advantage or disadvantage to one of the candidate who run in the election during campaign season".

Therefore, in its ruling, the court alter the mistake made by the legislator on the referral of the article. The court stated that the provision is unconstitutional unless "article 83 " on the provision are read "article 80 ". Another editorial mistake made by the legislator is found when the Court examine the judicial review on the Law no. 8 year $2015 .{ }^{68}$ Article 22B (d) of the Law mention "district/city election supervisory body [Bawaslu Kabupaten/Kota]". The court finds that there has been a clear mistake on the citation of "election supervisory body". The law should use the term of "election

\footnotetext{
67 Article 116 (4) of Law No. 32 year 2004 on Local Government

68 Rulings No. 51/PUU-XIII/2015
} 
supervisory committee [Panwaslu]" as provided and in accordance with article 1 (17) of the Law. ${ }^{69}$

\section{Interfere with temporal effect of decision/ legislation}

The court firstly introduces the terms 'conditionally constitutional' is in regards to the temporal effect of the decision. In the review of Water Resources Law, the Court argue that the Law on Water Resources have met with the constitutional principles which oblige the government to respect, protect and fulfill the rights to water. Nonetheless, if in the interpretation of the Law which will lay down in Government Regulation (Peraturan Pemerintah) were differ from the Court opinion then the Law is subject to a second judicial review. $^{70}$

The Court temporarily state the constitutionality of Water Resources Law until the enactment of Government Regulation that implemented the Law. Using the terms given by the Court, a second judicial review on Water Resources Law were submit by group of mass organizations and individuals in 2013. ${ }^{71}$ They argue that Government Regulation, especially Government Regulation No. 16 Year 2005 on Development of Drinking Water Supply System, which enacted as the implementation of Water Resources Law is not in conformity with the Court Opinion in the previous ruling. The Court conclude that not only Government Regulation No. 16 Year 2005 but also five others govern-

\footnotetext{
69 Ibid. Paragraph [3.26]

70 Rulings No. 058-059-060-063/PUU-II/2004 And 008/ PUU-III/2005, p. 495

71 Case/Rulings No. 85/PUU-XI/2013, submitted by Muhammadiyyah, Al Jami'atul Washliyah, Perkumpulan Vanaprashta, and individuals.
}

ment regulations issued as the implementation of Water Resources Law have breached the terms given by the Court. ${ }^{72}$ Therefore, the Court nullify the Water Resources Law and in order to avoid legislative vacuums on water management the Court revive the previous law on water, Law No. 11 Year 1974. This example also shows that in terms of temporal effect, the Court would reinstate an obsolete law.

In terms of applying the ruling model on postponing the effect of the decision, the Court not always specifically utter the phrase conditionally (un)constitutional. In deciding the constitutionality of budget allocation for education, the court intensively involves in the budget amendment between 2005 to $2008 .^{73}$ The constitutional amendment, which conducted in 1999-2002, clearly express that the budget allocation for education is at least twenty percent of the state budget. ${ }^{74}$

72 Rulings No. 85/PUU-XI/2013, Paragraph [3.30]: The Court set up six principles of water management, which are (i) business on water can not interfere, set aside, all the more neglect citizens rights to water, (ii) State obligation is to fulfill right to water, (iii) have to sustain the environment, (iv) state control and oversight on water is absolute, (v) main priority to be given access to water business is to state/local owned company, (vi) private company can have access to water business under strict conditions.

73 The court issues five Rulings which decided to revise state budget for education in each year, namely:

(i) Rulings Number 012/PUU-III/2005 on the Review of Law No. 36 Year 2004 on Annual State Budget of 2005;

(ii) Rulings Number 026/PUU-III/2005 on the Review of Law No. 13 Year 2005 on Annual State Budget of 2006;

(iii) Rulings Number 026/PUU-IV/2006 on the Review of Law No. 18 Year 2006 on Annual State Budget of 2007.

(iv) Rulings Number 24/PUU-IV/2007 on the Review of Law No. 18 Year 2006 on Annual State Budget of 2007 and the Law No. 20 Year 2003 on Nation Education System

(v) Rulings Number 13/PUU-VI/2008 on the Review of Law 16 Year 2008 on the Amendment of Law No. 45 Year 2007 on Annual State Budget of 2008

74 Article 31 (4) of the 1945 Constitution 
However, after the constitutional amendment the budget allocation never reach the constitutional provision. It prompted a few individuals to submit a petition to the Court. They argue that 2006 annual budget only gave $6 \%$ of the total for education wich was far less from the constitutional mandate. The court find that the government acknowledge this curtail budget. Yet, they defend that the education budget will be increase annually and will met the constitutional requirement in 2009. The court conclude that the government policy to increase education budget gradually is against the constitutional provision. ${ }^{75}$ The $20 \%$ budget allocation for education is a priority therefore the attainment of the provision by way of gradual approach is incompatible.

On the other side, the court also comprehend the notion that by nullifying the annual budget could stir financial disaster and only make things worst. Therefore, the court stand that the law on annual budget is unconstitutional since it did not allocate $20 \%$ amount of the total budget for education as required by the constitution. Nonetheless, there were strong and reasonable arguments which impeded the court to declare it null and void. The majority choose to declare the petittion inadmissable which lead to two of the judges to dissent. ${ }^{76}$ The next three cases on the review of education budget have the same issue. The government has not achieve the constitutionally arrange portion for education budget. The court stated that the budget limit set by the lawmakers is

75 Rulings No. 012/PUU-III/2005, p. 61

76 Achmad Roestandi and Soedarsono argued that the petition should be rejected because the government policy to increase education budget gradually is not against the constitution. unconstitutional but considering domestic and global financial situation it is necessary to confine legal effect of the rulings, especially on budget reallocation. ${ }^{77}$ The court take a stronger standing in the last education budget case by affirming the unconstitutionality of the law which provide the allocation for education budget is still under $20 \%$. Yet, the court postpone the effect of the ruling until the new law on annual budget are enacted. ${ }^{78}$

The court has issued 14 rulings which postponed the rulings to come into force. The reasons behind the court to postponed its judgment were vary. In terms of review which closely related to state budget administration, the court carefully consider the potential of financial turmoil. Therefore, the court take on the approach to postpone its decision. This argument can be found in the review of state allocation for education in its annual budget laws and also in the case of tobacco excises ${ }^{79}$ which related to the annual budget administration. The court also take the approach in considering the time that is need for the legislators to draft a new law. For instance, in the case of establishment of special court for graft cases ${ }^{80}$, the court recognize that in order to set up a smooth transition upon the revision of the new law, the court deem it is necessary to hold the enactment of the ruling which is up until three years after its deliberation.

\section{Interfere with the absence of legislation}

The role of the constitutional court is to control the constitutionality of legislation.

\footnotetext{
77 Rulings Nomor 026/PUU-III/2005. p. 86; see also Rulings 026/PUU-IV/2006, p. 95; also Rulings Number 24/ PUU-IV/2007, paragraph [3.16.9] and [3.16.10].

78 Rulings Number 13/PUU-VI/2008, paragraph [3.16]

79 Rulings number 54/PUU-VI/2008

80 Ruling number 012-016-019/PUU-IV/2006
} 
In that regards, the courts also seek the absence of legislation or the ommission of the statutes when the legislators does not comply with its constitutional obligation to legislate on specific matters or when the legislation has been issued in an incomplete way. This problem has captured the attention of many scholars and even there is an international congress dedicated to discuss the problem of legislative ommission. ${ }^{81}$ The report acknowledge that in many countries the courts have developed the technique in dealing with poor and incomplete legislation. The Courts choose to declare the insufficient provisions as unconstitutional but without annuling it. Rather, the Court sending directives and guidelines to the Legislator which may have obligatory character or even conceive as provisional pieces of legislation.

The Indonesian constitutional court has issued 18 rulings which have the character of filling the gap due to the ommission in the pieces of legislation. ${ }^{82}$ The law on Presidential Election provide that a citizen can only cast their vote only if they are register in the fixed voters list. This provision draw the attention of citizens who are not in the list to file a review case to the court. In the decision of the case, the court conclude that the provision which oblige a citizen to be register as voter in the fixed voters list is a part of administrative procedure. Thus, the procedure should not hinder citizen right to vote as their basic rights. Nonetheless, due to

81 General Report of the XIVth Congress of the Conference of European Constitutional Courts on Problems of Legislative Omission in Constitutional Jurisprudence, Strasbourg, December 2008, the Venice Commission, the full report can be found in http://www.venice.coe. int/files/Bulletin/SpecBull-legislative-omission-e.pdf.

82 See annex II. a time constraint, the citizens can not wait until the enactment of the revised law. The court, in its decision, find necessary to issues binding order to the election commission to fill the legal gap. The orders are (i) citizens who are not in the fixed voters list can cast their vote by showing their ID cards; (ii) ID cards must be incorporated with family certificate; (iii) must be use in the ballot station according to the address in the ID card; (iv) must self-register to the ballot station committee; (v) can only cast their vote one hour before closing.

The most recent case where the court deal with the legislative ommission is when it examine the contitutionality of a single candidate in the local election. The Law on the election of Governor, Head of District and Mayor provide that the local election can only be held if there is more than one (pair of) candidate. This provision neglected the fact that in some regions there are only one candidate running in the election. In its decision, the court support the possibility of a single candidate running in the election. The court also provide the mechanism of voting in great details by applying "agree" or "disagree" in the ballot design. This is intended to fill the legal gap due to the absence of legislation in the single candidacy.

\section{CONCLUSION}

In relation to its activist characteristic, the Indonesian Constitutional Court has issued atypical rulings. These rulings are not unique. The constitutional court in many countries also applies similar models. In comparative perspective, atypical rulings are not unusual. They have theoritical foundation with the 
Kelsenian approach that the court may sometime act as positive legislator. Yet, the Court introduce these special rulings by coin a phrase conditionally (un)constitutional. This idioms are use interchangeably and not always be adopt to identify the use of special rulings.

As the objective of this essay, it provide categorization of atypical rulings issued by the Court in 2005-2015. A strict grouping is hardly possible since the court may apply more than one category in a ruling. In addition, in a judicial review petition may contain few articles of a law to be challenge. Nonetheless, this essay identifies four categories of the special rulings, namely (i) adding new rules; (ii) altering the existing provision; (iii) interfere with temporal effect of the decision/legislation; and (iv) interfere with the absence of legislation. This sort of study is not new, but the idea behind this essay is to provide categorisation by using the latest source. It is important as a basis for further study on special rulings of the Court, especially the use of conditionally unconstitutional concept.

\section{BIBLIOGRAPHY}

Alec Stone Sweet. (2007) "The Politics of Constitutional Review in France and Europe," International Journal of Constitutional Law. 5(1). p. 84

Allan R. Brewer-Carias (2013) Constitutional Courts as Positive Legislators: A Comparative Law Study, Cambridge University Press.

Bjorn Dressel. (2012) 'The Judicialization of Politics in Asia: Towards a Framework of Analysis'. in Bjorn Dressel (ed). The Judicialization of Politics in Asia. Routledge, London, pp. 1-22;

Christine Landfried. "Judicial Policy Making in Germany: The Federal Constitutional Court”. pp 63-65, in Mary L. Volcansek (ed.). (1992) Judicial Politics and Policy-Making in Western Europe. London: Frank Cass.

Fritz Edward Siregar. (2015). "the Political Context of Judicial Review in Indonesia". Indonesia Law Review. 2(2): 235

Giancarlo Rolla and Tania Groppi. "Between Politics and the Law: The Development of Constitutional Review in Italy" in Wojciech Sadurski (ed). (2003). Constitutional Justice, East and West: Democratic Legitimacy and Constitutional Courts in Post-Communist Europe in a Comparative Perspective., The Hague-London-New York: Kluwer Law International. pp. 151-153

Hans Kelsen. (1942). “Judicial Review of Legislation: A Comparative Study of the Austrian and the American Constitution". The Journal of Politics. 4(2): 183

Leo Brust. (2009). "The Interpretation According to the Constitution and the Manipulative Judgments". Revista Direito GV Sao Paolo. 5(2): 136-152

Martin Shapiro and Alec Stone Sweet. (1994). "The New Constitutional Politic of Europe". Comparative Political Study. 26(4): 404.

Simon Butt. (2007). Judicial Review in Indonesia: Between Civil Law and Accountability? (PhD Dissertation, Melbourne University) 
Simon Butt. (2008) "Conditional Constitutionality, Pragmatism and the Rule of Law". Sydney Law School Research Paper No. 09/28. Available at SSRN: http://ssrn.com/abstract $=1400413$

Simone Penasa. "Constitutional Innovations Beyond Reforms: Legislative Enactment And Judicial Implementation Of The Constitution". in Giuseppe Bellantuono and Federico Puppo (eds.). (2015) Convergences And Divergences Between The Italian And The Brazilian Legal Systems. Università degli Studi di Trento. p. 47.

Stefanus Hendrianto (2016). "The Rise and Fall of Heroic Chief Justices: Constitutional Politics and Judicial Leadership in Indonesia". Washington International Law Journal, 2016, Forthcoming. pp 36-50. Can be access at http://papers.ssrn.com/sol3/papers. cfm?abstract_id=2629349.

Venice Commission. (2008). General Report of the XIVth Congress of the Conference of European Constitutional Courts on Problems of Legislative Omission in Constitutional Jurisprudence, Strasbourg. Full report can be found in http://www.venice.coe.int/ files/Bulletin/SpecBull-legislativeomission-e.pdf.

Vicki C. Jackson and Mark Tushnet. (2006). Comparative Constitutional Law. 2nd edition. New York: Foundation Press. p. 112

Victor Ferreres Comella. (2011). "Commentary: Courts in Latin America and the Constraints of the Civil Law Tradition". Texas Law Review. 89(1): 172174

Victor Ferreres Comella. (2004). "The Consequences of Centralizing Constitutional Review In A Special Court. Some Thoughts On Judicial Activism." SELA (Seminario en Latinoamérica de Teoría Constitucional y Política) Papers. 39: 14

Victor Ferreres Comella. (2004). "The European Model of Constitutional Review of Legislation: Toward Decentralization?". International Journal of Constitutional Law. 2(3): 487

Wojciech Sadurski. (2008). Rights Before Courts, A Study of Constitutional Courts in Postcommunist States of Central and eastern Europe. Netherlands: Springer. 